\title{
High Sensitivity C-Reactive Protein Measurement
}

National Cancer Institute

\section{Source}

National Cancer Institute. High Sensitivity C-Reactive Protein Measurement. NCI

Thesaurus. Code C157114.

The determination of the amount of C-reactive protein (CRP) present in a sample through the use of immunonephelometry, immunoturbidimetry, high-sensitivity enzymelinked immunosorbent assay (ELISA) and/or resonant acoustic profiling (RAP). This test is optimized to measure lower concentrations of CRP than a conventional CRP test. 